\title{
Socioeconomic differences in swimming ability among children in Malmö, southern Sweden - initial results from a community-level intervention
}

Frida I H Pilgaard ${ }^{1}$, Per-Olof Östergren ${ }^{1}$, Anna Olin², Stefan Kling ${ }^{3}$, Maria Albin, ${ }^{4,5}$, Jonas Björk $^{5,6}$

${ }^{1}$ Division of Social Medicine and Global Health, Department of Clinical Sciences Malmö, Lund University, Sweden

${ }^{2}$ Primary School Administration, Department of Student Health, City of Malmö, Sweden ${ }^{3}$ Department of Child and Adolescent Psychiatry, Lund University Hospital, Lund, Sweden ${ }^{4}$ Unit of Occupational Medicine, Institute of Environmental Medicine, Karolinska Institute, Sweden

${ }^{5}$ Division of Occupational and Environmental Medicine, Lund University Sweden ${ }^{6}$ Clinical Studies Sweden, Forum South, Skåne University Hospital, Lund, Sweden

Corresponding author: Jonas Björk, Division of Occupational and Environmental Medicine, Lund University, SE-22100 LUND, Sweden. E-mail jonas.bjork@med.lu.se 


\title{
Abstract (max 250 words)
}

\author{
Aims \\ To investigate to what extent socioeconomic differences in swimming abilities persist among \\ children in the city of Malmö, Sweden, after a community-level swimming intervention \\ programme in public primary schools.

\section{Methods}

A compulsory swimming education programme was launched in 2014 in second grade (at age 8) in all public primary schools in Malmö, Sweden. Data for the present study on sociodemographic conditions and self-reported swimming ability in fourth grade (age 10) were used for the last birth cohort unexposed $(n=1695)$ and the first birth cohort exposed $(\mathrm{n}=1773)$ to the intervention.

\section{Results}

The swimming ability was $78 \%$ and $77 \%$, respectively, in the pre- and post-intervention cohorts. Significantly lower self-reported swimming ability was found both pre- and postintervention among children with support activities in school, with parents born outside Europe, North America and Australia, with manual working, unemployed or studying parents and in children enrolled in schools with socioeconomic index below median.

\section{Conclusions}

The findings do not suggest that sociodemographic differences in swimming ability have decreased in the first birth cohort exposed to the community-level intervention in Malmö. Striking differences in self-reported swimming ability were noted when the children reached the fourth grade both pre- and post-intervention with marked lower abilities in socially disadvantaged groups. Monitoring of swimming abilities should continue for the present and similar interventions aiming at reducing inequalities among children. Efforts to increase water comfort already at preschool age ought to be considered.

Key words: socioeconomic factors, exercise, swimming, intervention study, physical education and training

Word count: 2567 


\section{Background}

Swimming ability is essential for handling emergency situations in water, and is therefore a potentially life-saving skill. Further, swimming and other water-based activities improve physical and mental health throughout life [1-3]. The World Health Organization (WHO) estimates drowning to be the third leading cause of unintentional deaths in the world, causing close to 400000 deaths in 2012 [4]. About $90 \%$ of these deaths occurred in low- and middleincome countries. In high income countries the drowning rate has been estimated to be 2.3 cases per 100000 population and year [4]. The drowning rate has continuously dropped in Sweden during the $20^{\text {th }}$ century from 22 to 1.4 deaths per 100000 population, mainly due to prevention efforts including teaching swimming skills [5]. However, drowning is still the third leading cause of injury-related deaths (including suicide) among children aged 0-14, with on average 5.2 drowning cases each year during 2012-2016 [6]. Drowning rates are linked to socioeconomic status (SES) and country of origin. A case analysis of all children's drowning deaths occurring in Sweden 1998-2007 showed that children with immigrant background, particularly from the Middle East and Iran, were overrepresented [7].

Children develop individually and might not be ready to learn to swim at the same age. However, there are studies indicating that swimming skills can be taught at preschool ages and swimming lessons in children even as young as 1-4 years old may reduce the risk of drowning [8-10]. In a study from Australia the optimal readiness period to learn to swim was identified to be between 5 and 6 years of age [11]. This study also showed that the children learned to swim 10 meters front crawl at approximately the same mean age of $51 / 2$ years, irrespectively of whether they started to take lessons at 2, 3 or 4 years of age. A Danish review identified the ideal age to learn to swim to be 8 years of age, given that the child at the age of 5-7 has participated in water activities and has become comfortable in the water [12]. The Swedish National Agency for Education reports that children who receive swimming 
education already in preschool or in first grade (at age 7) have a higher probability to pass a swimming ability test in grade six compared to children who start their swimming education in second grade or later [13].

In Sweden swimming education is part of the primary school curriculum. In grade 1-3 when the children are 7-9 years old the activities focus on making the children feel comfortable in the water and in grade 4-6 on swimming ability. In grade 6 and 9 the children must pass a swimming ability test to pass the physical education and health course [14]. To pass the test the child has to swim continuously for 200 meters, of which at least 50 meters on backstroke, which is in line with the common Nordic swimming ability definition. Subsequently, if a child lacks swimming ability in grade 6 this will have a negative impact on school grades. If the child still cannot swim in grade 9 this will have a negative impact on the chances to enter upper secondary school programmes due to incomplete school grades.

Although swimming is part of the school curriculum low swimming ability among children has been reported from several municipalities in Sweden, especially in areas with a high proportion of families with a low SES and immigrant background [15]. Data from the city of Malmö from 2011 showed that the swimming ability among children in grade 5 varied markedly between areas [16]. As an example, in one of the socioeconomically disadvantaged areas (Rosengård) the swimming ability was $27 \%$ compared to $93 \%$ in the socioeconomically highest ranked area (Limhamn-Bunkeflo). In order to decrease these differences in swimming ability, the city of Malmö launched a community-level swimming intervention programme in 2014 among school children. The aim of the present study was to investigate to what extent the socioeconomic differences in swimming abilities persist in the first cohort exposed to this intervention programme. The study was approved by the regional ethical board in Lund, Sweden, and is part of BlueHealth (www.bluehealth2020.eu), a project that has received funding from the European Union's Horizon 2020 research and innovation programme. This 
project aims to explore the benefits to human health and well-being associated with interacting with blue space (i.e. water) across Europe [17].

\section{Methods}

\section{Swimming education in schools before intervention}

The organisation of the swimming education in Sweden is not regulated in the school curriculum or elsewhere, and the education therefore varies between different municipalities and schools. In Malmö, each school administration paid and organized their swimming education separately up to 2014 . This led to differences in swimming education delivered to the children depending on priorities made by each school. The overall picture of how the schools organized their swimming education before 2014 is fragmented, as each school contacted swimming halls directly to reserve timeslots in order to arrange swimming lessons.

\section{Community-level intervention}

To improve the swimming abilities and make them more equal the city administration of Malmö in 2014 launched a compulsory swimming education programme, Skolsim ("School Swim") in second grade in all public primary schools, comprising about 3000 children each year. This community-level intervention was organised by the Leisure and Recreation Services Department and payed for by the Primary School Department, i.e. not by the schools themselves. The main aim of the programme was to make the children comfortable in the water, which is a prerequisite for learning how to swim. The programme consisted of a threeweek swimming education intervention including 15 swimming lessons of $45 \mathrm{~min}$. Each class with about 20-30 children was divided into three groups depending on prior swimming skills. Three educated swimming teachers then provided the appropriate swimming education to each group (one teacher per group). 


\section{Data collection}

Health examinations are offered to all children in preschool and in grades 4, 7 and 8 in primary schools in the city of Malmö. The main objective of these health examinations is to be supportive for the children and to maintain or improve their wellbeing so that they can participate in and fulfil school tasks. Starting in the school year 2015/2016 anonymized data from the health examinations have been entered into the Pupil Health Database (ELSA) by school nurses in all public schools. Public schools constitute about $75 \%$ of all schools in Malmö. Background information from two questionnaires, one administered to the child and one to a parent, is also added into the database after permission from the parents. Data for the present study were retrieved regarding health status, family and socioeconomic situation. Selfreported swimming ability was obtained from the questionnaire statement "I can swim 200 meters" to which the child answered "yes" or "no". We used the particular socioeconomic index for each school that is routinely calculated by Statistics Sweden based on the following information about the school children: sex, the time of arrival in Sweden if immigrated, education of the parents, whether the parents are receiving financial aid, whether the child lives with one or both parents.

\section{Study population}

All children in second grade in a public primary school in Malmö, either in 2013/14 that was the last year before the swimming intervention started, or in 2014/15 that was the first year with the intervention, were eligible for the present study. Data from the health examinations in the fourth grade for these two cohorts were available in the Pupil Health Database ( $n=2062$ and 2 180, respectively). Children born outside Sweden $(n=708,338$ in the pre-intervention and 370 in the post intervention group) were excluded from the analysis to minimize the risk of including newly arrived immigrant children who had not taken part in the intervention two years earlier. An additional 62 children (26 pre-intervention and 36 post-intervention) were 
excluded from the analysis because of missing data on swimming ability. Also, four children (three pre-intervention and one post-intervention) attending a school for autistic children were excluded, leaving 3468 children in the final study cohort, 1695 in the pre-intervention and 1773 in the post-intervention cohort. Both cohorts were similar with respect to sociodemographic variables (Table 1).

\section{Statistical analysis}

We used logistic regression to assess the effect of the intervention on the binary outcome variable self-reported swimming ability $(1=$ Able to swim 200 meters, $0=$ Not able $)$, both in single-predictor logistic regression models and in multivariable models with adjustment for the sociodemographic variables on the individual and school levels listed in Table 1. Odds ratios (ORs) below one in the logistic regression analyses thus imply decreased odds of reporting ability to swim 200 meters. All variables were categorized in the regression analyses as presented in Table 1. Logistic regression analyses were also conducted in the pre- and postintervention cohort separately to further investigate if the intervention influenced the associations between the sociodemographic variables and swimming ability. The statistical analyses were performed in STATA 13.1 (StataCorp, USA).

\section{Results}

\section{Intervention uptake and attendance}

The school year 2014/15 was the first year of the intervention. This year the intervention covered all second grade classes in all public primary schools, in total 2906 children. Eightyfour percent of the children attended at least 12 out of $15(80 \%)$ of all swimming lessons. This attendance rate varied between $60-97 \%$ across schools. 


\section{Tested swimming ability in connection with the intervention}

No data on tested swimming ability at start of the intervention were available. However, at the end of the three-week intervention the children were tested concerning comfort in water and swimming ability. A child was assessed to be comfortable in the water if he/she could "streamline" for 5 seconds, meaning to float with straight arms and head under water for 5 seconds. The proportion of children assessed to be comfortable in water was $91 \%$, varying between $59-100 \%$ across schools. Swimming ability directly after the intervention according to the Nordic standard definition was assessed to be $28 \%$ among all children, varying between $0-67 \%$ across schools.

The swimming ability was lower (20\%) among children who had an attendance rate of less than $80 \%$ compared to the children who attended $80 \%$ or more of the lessons (swimming ability of $30 \%)$.

\section{Estimated intervention effect in grade 4}

The overall self-reported swimming ability in grade 4, i.e. two years after intervention or control education, was $78 \%$ in the pre-intervention cohort and $77 \%$ in the post-intervention cohort (Table 1). All sociodemographic variables except sex were associated with swimming ability in single-predictor models (Table 2, Model type I). No significant difference in swimming ability was found between the pre- and post-intervention cohorts, neither in unadjusted nor in multivariable analyses. Swimming ability in the multivariable analysis was lower among children with support activities in school, with parents born outside Europe, North America and Australia, with manual working, unemployed or studying parents and in children enrolled in schools with socioeconomic index below median (Table 2, Model II). In the separate analyses of the pre- and post-intervention cohorts no elear effects of decreaseddecreases in socioeconomic inequalities in swimming ability were suggested (Table 2, Model III - IV). 


\section{Discussion}

Our evaluation of the community-level swimming programme Skolsim does not suggest that sociodemographic differences in swimming ability have decreased in the first birth cohort exposed to the intervention. Striking differences in self-reported swimming ability were noted when the children reached the fourth grade both pre- and post-intervention with marked lower abilities in socially disadvantaged groups.

A major strength of the present study was the size of two cohorts pre- and post-intervention with data on sociodemographic conditions both at the individual and the school level. The intervention uptake was relatively high, and so was participation in the health examinations entered in the Pupil Health Database, which limit the risk of selection bias in the presented results. An important limitation was that only data on self-reported, i.e. not tested or documented in e.g. school grades, swimming abilities are currently available. Previous studies have found that young adults have a tendency to underestimate their distance swimming skills when compared to actual swimming competence $[18,19]$, but it is unclear to what extent these results can be generalized to our cohorts. It is however reasonable to assume that any misclassification of the swimming ability was non-differential with respect to the intervention, resulting in bias towards the null. Another limitation of the study was that information about how the swimming education was organised before the intervention is limited, as this was the responsibility of each school. We therefore lack measures on the number of additional swimming lessons that were given with the intervention, and also do not know to what extent the content of lessons were changed.

The present study showed that country of birth and occupation of the parents were strongly related to swimming ability among the children. The results further suggested that swimming ability was lower among children enrolled in or in need of support activities in school. These findings can be used to target groups of children with greater needs of support in their 
swimming training. Additional free swimming lessons mainly targeting these groups of children at different ages from preschool and onwards might reduce differences in swimming ability. Markedly lower swimming ability was seen among children enrolled at the schools with socioeconomic index below median, also after controlling for sociodemographic variables on the individual_-level. This finding suggests that the context and the general school environment is important also for the success of swimming education and that more directed interventions towards the schools with lower socioeconomic index could be beneficial.

Being comfortable in the water is a prerequisite to learn how to swim, and water comfort can be taught already at preschool age [8-10]. Starting swimming lessons at an earlier age is likely not only to improve overall swimming abilities, but would also reduce the number of years with elevated risk of drowning. In 2017 the city of Gothenburg, Sweden, launched a large swimming education programme (Simlyftet) to reduce inequalities in swimming ability [20]. Based on the knowledge that swimming education is most effective at an early age, swimming lessons in the Gothenburg intervention have been introduced for all children already in preschool (6 years) as well as in grade 2. Further, all children who cannot swim in grade 5-9 in Gothenburg are also offered free swimming lessons. It is conceivable that an important reason why the Skolsim intervention in Malmö has so far not achieved its goals is that it is currently lacking an effort to achieve water comfort in children already in preschool. If water comfort is achieved at an earlier age, the aim of swimming lessons provided by the school in the second grade could be more directed towards learning how to swim.

The swimming intervention in Malmö is on-going, and it is therefore highly relevant to continue to monitor intervention effects, at age 10 but also at age 12 when the children receive grades in the physical education and health course (where swimming ability is prerequisite in order to pass the course). Structured evaluations of other on-going interventions, such as the 
comprehensive swimming education programme in Gothenburg, Sweden [20], should also be given priority. Lastly, it is also of interest to investigate correlates of swimming difficulties with respect to health and school situation, and to conduct more in depth studies among both children and parents in order to better understand how improved and more equal swimming abilities can be achieved. 


\section{Acknowledgements}

This project has received funding from the European Union's Horizon 2020 research and innovation programme under grant agreement No 666773. The project has also received financial support from the Swedish Research Council (grant no. 340-2013-5474). 


\section{References}

1. Cox KL, Burke V, Beilin LJ, et al. A comparison of the effects of swimming and walking on body weight, fat distribution, lipids, glucose, and insulin in older women-the Sedentary Women Exercise Adherence Trial. Metab. Clin. Exp, 2010;59:1562-73.

2. Alkatan M, Machin DR, Baker JR. Effects of Swimming and Cycling Exercise Intervention on Vascular Function in Patients With Osteoarthritis. Am J Cardiol 2016;117:141-145

3. Gates A, Cumming I. The Health and Wellbeing Benefits of Swimming. Report commissioned by the Swimming and Health Commission on behalf of Swim England. Report No. ISBN 978-1-9997622-0-9 June 2017. http://tinyurl.com/y8qs9mv3 (accessed 26 Feb 2018).

4. World Health Organization. World report on child injury prevention. Report ISBN 978 924156357 4, Switzerland, 2008.

5. Swedish Life Saving Society. http://www.svenskalivraddningssallskapet.se/om-oss/dethar-ar-vi/var-historia (accessed 2018 March 06).

6. Dödsorsaksstatistik 1997-2016 [Cause of death statistics 1997-2016] [database on the Internet]. Stockholm: The National Board of Health and Welfare. (accessed 2018 Feb 26). Available from: http://www.socialstyrelsen.se/statistics/statisticaldatabase/causeofdeath

7. MSB - Swedish Civil Contingencies Agency. Varför drunknar barn? En retrospektiv studie över barn som drunknat i Sverige 1998-2007 [Why do children drown? A retrospective study of drowning deaths among children in Sweden 1998-2007]. Report no. MSB 0139-10 ISBN 978-91-7383-062-1, 2010.

8. Brenner RA, Taneja GS, Haynie DL, et al. Association between swimming lessons and drowning in childhood: a case-control study. Arch Pediatr Adolesc Med 2009;163:203-10.

9. Yang L, Nong QQ, Li CL, et al. Risk factors for childhood drowning in rural regions of a developing country: a case-control study. Inj Prev 2007;13:178-82. 
10. Asher KN, Rivera FP, Felix D, et al. Water safety training as a potential means of reducing risk of young children's drowning. Inj Prev 1995;1:228-33.

11. Blanksby B, Parker H, Bradley S, et al. Children's readiness for learning front crawl swim. J Sci Med Sport 1995;27:34-7.

12. Lüders K, Dalsgaard J, Knudsen LS, et al. Delundersøgelse 1 - Forbedring af børns svømmeduelighed: Et litteraturstudie af hvilken alder og hvilken stilart der er mest effektiv, når børn skal lære at svømme [Sub study 1 - Improved swimming abilities in children: a review of what age and what method is most effective when children learn how to swim]. Print \& Sign, Odense: Forsknings- og Innovationscenter for Idræt, Bevægelse og Læring, Syddansk Universitet \& University College Lillebælt, 2015. 63 s. (REACH; Nr. 2015:1).

13. Swedish National Agency for Education. Simkunnighet i årskurs 6, Uppföljning av kunskapskraven i idrott och hälsa avseende simkunnighet samt förmåga att hantera nödsituationer vid vatten läsåret 2013/14 [Swimming ability in grade 6, Follow-up of requirements in physical education and health regarding swimming skills and ability to handle emergency situations in water 2013/14]. Report No (Dnr) 5.1.3-2014:402, 2014.

14. Swedish National Agency for Education. Kursplan - Idrott och hälsa [Syllabus - Physical education and health]. www.skolverket.se/laroplaner-amnen-och kurser/grundskoleutbildning/grundskola/idrott-och-halsa\#anchor1 (accessed 26 February 2018).

15. City of Gothenburg. Utredning om avgiftsfri simundervisning Slutrapport [nquiry on free swimming lessons, final report]. Report 2017-03-20.

16. City of Malmö. Stadskontoret Malmö stads välfärdsredovisning 2013 [City of Malmö, Town office, Welfare report 2013]. Report. Available: http://redovisningar.malmo.se/2013/assets/Valfardsredovisning_2013.pdf 
17. Grellier J, White MP, Albin M, et al. BlueHealth: a study programme protocol for mapping and quantifying the potential benefits to public health and well-being from Europe's blue spaces. BMJ Open 2017;7:e016188.

18. Petrass LA, Blitvich JD, McElroy GK, et al. Can You Swim? Self-Report and Actual Swimming Competence Among Young Adults in Ballarat, Australia. IJARE 2012;6:136148.

19. Moran M, Stallman R K, Kjendlie P-L, et al. Can You Swim? An exploration of Measuring Real and Perceived Water Competency. IJARE 2012;6:122-135.

20. City of Gothenburg. http://goteborg.se/wps/portal/enhetssida/simskola/om-simskolan (accessed 2018 March 06). 


\section{Tables}

Table 1. Sociodemographic variables and self-reported swimming ability among children of grade 4 (age 10 - 11) in public primary schools in the city of Malmö, stratified according to exposure to control education (pre-intervention cohort) or the community-level swimming intervention Skolsim (post-intervention cohort).

\begin{tabular}{|c|c|c|c|c|}
\hline & $\begin{array}{l}\text { Pre- } \\
\text { intervention } \\
\text { cohort } \\
(n=1695)\end{array}$ & $\begin{array}{l}\text { Self-reported } \\
\text { swimming ability (pre- } \\
\text { intervention cohort) }\end{array}$ & $\begin{array}{l}\text { Post- } \\
\text { intervention } \\
\text { cohort } \\
(n=1773)\end{array}$ & $\begin{array}{l}\text { Self-reported } \\
\text { swimming ability } \\
\text { (post-intervention } \\
\text { cohort) }\end{array}$ \\
\hline All & & $78.2 \%$ & & $77.0 \%$ \\
\hline \multicolumn{5}{|l|}{ Sociodemographic variables } \\
\hline \multicolumn{5}{|l|}{ Sex } \\
\hline Missing data & 0 & - & 0 & - \\
\hline Male & $50.0 \%$ & $77.3 \%$ & $50.8 \%$ & $76.8 \%$ \\
\hline Female & $50.0 \%$ & $79.0 \%$ & $49.2 \%$ & $77.2 \%$ \\
\hline $\begin{array}{l}\text { Enrolled in/in need of support } \\
\text { activities in school }\end{array}$ & $12.7 \%$ & $65.6 \%$ & $12.1 \%$ & $61.5 \%$ \\
\hline Missing data & 0 & - & 167 & $70.7 \%$ \\
\hline $\begin{array}{l}\text { Limited partaking in school due to } \\
\text { disease or disability }\end{array}$ & $10.1 \%$ & $67.7 \%$ & $10.5 \%$ & $67.0 \%$ \\
\hline Missing data & 682 & $78.2 \%$ & 736 & $74.3 \%$ \\
\hline \multicolumn{5}{|l|}{ BMI } \\
\hline Missing data & 0 & - & 0 & - \\
\hline Underweight & $3.8 \%$ & $69.2 \%$ & $4.3 \%$ & $71.0 \%$ \\
\hline Normal weight & $74.3 \%$ & $79.4 \%$ & $72.8 \%$ & $78.4 \%$ \\
\hline Overweight & $17.4 \%$ & $76.9 \%$ & $17.0 \%$ & $73.2 \%$ \\
\hline Obesity & $4.5 \%$ & $70.1 \%$ & $5.9 \%$ & $75.2 \%$ \\
\hline \multicolumn{5}{|l|}{ Siblings } \\
\hline Missing data & 15 & $80.0 \%$ & 12 & $91.7 \%$ \\
\hline No siblings & $7.7 \%$ & $79.2 \%$ & $7.6 \%$ & $79.7 \%$ \\
\hline One sibling & $47.6 \%$ & $85.1 \%$ & $46.1 \%$ & $84.4 \%$ \\
\hline Two or more siblings & $44.6 \%$ & $70.5 \%$ & $46.3 \%$ & $69.0 \%$ \\
\hline \multicolumn{5}{|l|}{ Family situation } \\
\hline Missing data & 0 & - & 15 & $80 \%$ \\
\hline Lives with both parents & $74.6 \%$ & $78.8 \%$ & $72.6 \%$ & $78.5 \%$ \\
\hline $\begin{array}{l}\text { Lives with both parents } \\
\text { alternately }\end{array}$ & $12.3 \%$ & $83.7 \%$ & $12.5 \%$ & $81.3 \%$ \\
\hline $\begin{array}{l}\text { Lives with one parent, } \\
\text { foster home or another } \\
\text { adult }\end{array}$ & $13.2 \%$ & $69.5 \%$ & $15.0 \%$ & $65.8 \%$ \\
\hline
\end{tabular}




\begin{tabular}{|c|c|c|c|c|}
\hline \multicolumn{5}{|l|}{ Country of birth parents } \\
\hline Missing data & 6 & $66.7 \%$ & 21 & $57.1 \%$ \\
\hline $\begin{array}{l}\text { Both from Sweden/other } \\
\text { Nordic country }\end{array}$ & $50.0 \%$ & $88.6 \%$ & $47.3 \%$ & $87.3 \%$ \\
\hline $\begin{array}{l}\text { One from Sweden/other } \\
\text { Nordic country one from an } \\
\text { other country }\end{array}$ & $15.9 \%$ & $80.2 \%$ & $13.9 \%$ & $85.2 \%$ \\
\hline $\begin{array}{l}\text { At least one from the rest of } \\
\text { Europe (not Nordic } \\
\text { country), North America or } \\
\text { Australia }\end{array}$ & $13.0 \%$ & $73.2 \%$ & $16.3 \%$ & $73.7 \%$ \\
\hline $\begin{array}{l}\text { Both from the rest of the } \\
\text { world (not Europe, North } \\
\text { America or Australia) }\end{array}$ & $21.1 \%$ & $55.2 \%$ & $22.6 \%$ & $53.8 \%$ \\
\hline \multicolumn{5}{|l|}{ Employment parents } \\
\hline Missing data & 250 & $65.2 \%$ & 174 & $59.2 \%$ \\
\hline $\begin{array}{l}\text { Both non- manual } \\
\text { employees }\end{array}$ & $43.7 \%$ & $90.8 \%$ & $47.8 \%$ & $88.8 \%$ \\
\hline $\begin{array}{l}\text { One non- manual employee } \\
\text { one other }\end{array}$ & $16.2 \%$ & $84.6 \%$ & $16.4 \%$ & $79.8 \%$ \\
\hline Both manual workers & $30.4 \%$ & $73.1 \%$ & $24.5 \%$ & $71.1 \%$ \\
\hline $\begin{array}{l}\text { One manual worker, one } \\
\text { other (not non- manual } \\
\text { employees) }\end{array}$ & $5.1 \%$ & $56.2 \%$ & $5.9 \%$ & $54.3 \%$ \\
\hline $\begin{array}{l}\text { Both unemployed, studying } \\
\text { or other }\end{array}$ & $4.8 \%$ & $43.5 \%$ & $5.4 \%$ & $51.7 \%$ \\
\hline \multicolumn{5}{|l|}{$\begin{array}{l}\text { Socioeconomic index at school } \\
\text { level }\end{array}$} \\
\hline Missing data & 0 & - & 0 & - \\
\hline 1st quartile, lowest index & $24.5 \%$ & $58.2 \%$ & $26.4 \%$ & $56.8 \%$ \\
\hline 2nd quartile & $23.2 \%$ & $75.6 \%$ & $26.7 \%$ & $78.0 \%$ \\
\hline 3rd quartile & $26.0 \%$ & $89.1 \%$ & $23.2 \%$ & $87.4 \%$ \\
\hline 4th quartile, highest index & $26.3 \%$ & $88.3 \%$ & $23.7 \%$ & $88.1 \%$ \\
\hline
\end{tabular}


Table 2. Estimated effect of community-level swimming intervention on swimming ability and associations with sociodemographic variables in bi- and multivariable logistic regression analyses where ORs below one imply decreased odds of reporting ability to swim 200 meters.

\begin{tabular}{|c|c|c|c|c|}
\hline & $\begin{array}{l}\text { Model type I } \\
\text { Single-predictor } \\
\text { models OR ( } 95 \% \\
\mathrm{CI}), \text { pre- and } \\
\text { post- } \\
\text { intervention } \\
\text { cohort together }\end{array}$ & $\begin{array}{l}\text { Model II } \\
\text { Multivariable model } \\
\text { OR }(95 \% \mathrm{Cl}) \text {, pre- } \\
\text { and post- } \\
\text { intervention cohort } \\
\text { together }\end{array}$ & $\begin{array}{l}\text { Model III } \\
\text { Multivariable } \\
\text { model OR }(95 \% \\
\mathrm{CI}) \text { pre- } \\
\text { intervention } \\
\text { cohort }\end{array}$ & $\begin{array}{l}\text { Model IV } \\
\text { Multivariable } \\
\text { model OR }(95 \% \mathrm{CI}) \\
\text { post-intervention } \\
\text { cohort }\end{array}$ \\
\hline Post-intervention cohort & $0.93(0.79-1.10)$ & $1.03(0.84-1.27)$ & & \\
\hline Pre-intervention cohort & 1.0 (Reference) & 1.0 (Reference) & & \\
\hline \multicolumn{5}{|l|}{ Sociodemographic variables } \\
\hline \multicolumn{5}{|l|}{ Sex } \\
\hline Female & 1.0 (Reference) & 1.0 (Reference) & 1.0 (Reference) & 1.0 (Reference) \\
\hline Male & $0.94(0.80-1.10)$ & $0.96(0.78-1.17)$ & $0.95(0.71-1.27)$ & $1.00(0.75-1.33)$ \\
\hline $\begin{array}{l}\text { Enrolled in/in need of support } \\
\text { activities in school }\end{array}$ & $0.44(0.35-0.55)$ & $0.47(0.35-0.63)$ & $0.53(0.35-0.81)$ & $0.41(0.27-0.63)$ \\
\hline $\begin{array}{l}\text { Limited partaking in school due to } \\
\text { disease or disability }\end{array}$ & $0.57(0.42-0.77)$ & $0.73(0.49-1.08)$ & $0.72(0.41-1.26)$ & $0.75(0.43-1.32)$ \\
\hline \multicolumn{5}{|l|}{$\mathrm{BMI}$} \\
\hline Underweight & $0.63(0.43-0.92)$ & $0.52(0.32-0.83)$ & $0.41(0.21-0.81)$ & $0.60(0.32-1.14)$ \\
\hline Normal weight & 1.0 (Reference) & 1.0 (Reference) & 1.0 (Reference) & 1.0 (Reference) \\
\hline Overweight & $0.80(0.65-0.99)$ & $0.92(0.71-1.19)$ & $0.96(0.66-1.40)$ & $0.87(0.61-1.25)$ \\
\hline Obesity & $0.73(0.52-1.02)$ & $1.15(0.74-1.78)$ & $0.88(0.47-1.67)$ & $1.49(0.80-2.76)$ \\
\hline \multicolumn{5}{|l|}{ Siblings } \\
\hline No siblings & 1.0 (Reference) & 1.0 (Reference) & 1.0 (Reference) & 1.0 (Reference) \\
\hline One sibling & 1.43 (1.03-1.99) & $0.99(0.66-1.51)$ & $1.15(0.64-2.06)$ & $0.91(0.50-1.65)$ \\
\hline Two or more siblings & $0.60(0.43-0.81)$ & $0.73(0.48-1.10)$ & $0.91(0.51-1.64)$ & $0.61(0.34-1.10)$ \\
\hline \multicolumn{5}{|l|}{ Family situation } \\
\hline Lives with both parents & 1.0 (Reference) & 1.0 (Reference) & 1.0 (Reference) & 1.0 (Reference) \\
\hline $\begin{array}{l}\text { Lives with both parents } \\
\text { alternately }\end{array}$ & $1.27(0.98-1.66)$ & $0.86(0.63-1.18)$ & $1.10(0.69-1.74)$ & $0.67(0.43-1.04)$ \\
\hline $\begin{array}{l}\text { Lives with one parent, } \\
\text { foster home or another } \\
\text { adult }\end{array}$ & $0.56(0.46-0.70)$ & $0.84(0.63-1.12)$ & $0.94(0.61-1.45)$ & $0.80(0.54-1.19)$ \\
\hline \multicolumn{5}{|l|}{ Country of birth parents } \\
\hline $\begin{array}{l}\text { Both from Sweden/other } \\
\text { Nordic country }\end{array}$ & 1.0 (Reference) & 1.0 (Reference) & 1.0 (Reference) & 1.0 (Reference) \\
\hline $\begin{array}{l}\text { One from Sweden/other } \\
\text { Nordic country one from } \\
\text { another country }\end{array}$ & $0.65(0.49-0.85)$ & $1.01(0.73-1.39)$ & $0.92(0.60-1.41)$ & $1.20(0.72-1.95)$ \\
\hline $\begin{array}{l}\text { At least one from the rest } \\
\text { of Europe (not Nordic } \\
\text { country), North America or } \\
\text { Australia) }\end{array}$ & $0.38(0.30-0.48)$ & $0.70(0.51-0.97)$ & $0.79(0.49-1.27)$ & $0.63(0.40-0.99)$ \\
\hline
\end{tabular}




\begin{tabular}{|c|c|c|c|c|}
\hline $\begin{array}{l}\text { Both from the rest of the } \\
\text { world (not Europe, North } \\
\text { America or Australia) }\end{array}$ & $0.16(0.13-0.20)$ & $0.41(0.31-0.56)$ & $0.41(0.27-.63)$ & $0.40(0.26-0.61)$ \\
\hline \multicolumn{5}{|l|}{ Employment parents } \\
\hline $\begin{array}{l}\text { Both non- manual } \\
\text { employees }\end{array}$ & 1.0 (Reference) & 1.0 (Reference) & 1.0 (Reference) & 1.0 (Reference) \\
\hline $\begin{array}{l}\text { One non- manual } \\
\text { employee one other }\end{array}$ & $0.52(0.39-0.70)$ & $0.65(0.48-0.89)$ & $0.69(0.43-1.10)$ & $0.64(0.42-0.98)$ \\
\hline Both manual workers & $0.30(0.24-0.38)$ & $0.57(0.43-0.75)$ & $0.50(0.33-0.75)$ & $0.64(0.43-0.96)$ \\
\hline $\begin{array}{l}\text { One manual worker, one } \\
\text { other (not non- manual } \\
\text { employees) }\end{array}$ & $0.14(0.10-0.20)$ & $0.38(0.25-0.58)$ & $0.27(0.15-0.50)$ & $0.52(0.29-0.93)$ \\
\hline $\begin{array}{l}\text { Both unemployed, } \\
\text { studying or other }\end{array}$ & $0.11(0.07-0.15)$ & $0.34(0.22-0.53)$ & $0.22(0.11-0.43)$ & $0.51(0.27-0.94)$ \\
\hline \multicolumn{5}{|l|}{$\begin{array}{l}\text { Socioeconomic status at school } \\
\text { level - based on index }\end{array}$} \\
\hline 1st quartile, lowest index & $0.18(0.14-0.23)$ & $0.49(0.34-0.68)$ & $0.54(0.33-0.87)$ & $0.43(0.26-0.70)$ \\
\hline 2nd quartile & $0.45(0.34-0.58)$ & $0.68(0.50-0.93)$ & $0.72(0.46-1.13)$ & $0.66(0.42-1.04)$ \\
\hline 3rd quartile & $1.01(0.75-1.35)$ & $1.07(0.77-1.49)$ & $1.13(0.71-1.80)$ & $1.03(0.64-1.69)$ \\
\hline 4th quartile, highest index & 1.0 (Reference) & 1.0 (Reference) & 1.0 (Reference) & 1.0 (Reference) \\
\hline
\end{tabular}

